University of Konstanz

Department of Economics

\title{
Globalization's Winners and Losers
}

Evidence from Life Satisfaction Data, 1975 - 2001

Zohal Hessami

Working Paper Series

2011-12 


\title{
Globalization's Winners and Losers
}

\author{
Evidence from Life Satisfaction Data, 1975 - 2001
}

\author{
Zohal Hessami * \\ Department of Economics and Zukunftskolleg \\ University of Konstanz, Box 138, 78457 Konstanz, Germany
}

\begin{abstract}
This paper analyzes the effect of globalization on subjective well-being by using a dataset that combines micro- and macro-level variables for the EU-15 countries from 1975 to 2001 . The estimations provide evidence that - in line with theoretical predictions - globalization has benefited especially highskilled workers, right-wing voters, respondents that trust the WTO, the World Bank, and the IMF as well as respondents in the highest income quartile. In addition, globalization has increased well-being to a higher extent for old people than for young people.
\end{abstract}

Keywords: Life satisfaction; Well-being; Globalization; Heckscher-Ohlin theorem JEL codes: F15; F16; I31

\footnotetext{
* Phone: $\quad+497531884928$

Fax: $\quad+497531883130$

E-mail address: Zohal.Hessami@uni-konstanz.de
} 


\section{Introduction}

The economic literature provides evidence that globalization is beneficial in terms of macroeconomic performance (Dreher, 2006) and increasing product variety (Broda and Weinstein, 2006), while income inequality between (Dutt and Mukhopadhyay, 2005) and within countries (Dreher and Gaston, 2008) has been exacerbated in a globalized world. At the same time, there is a growing literature investigating the effect of country-level variables on individuals' subjective wellbeing (Di Tella et al. 2001; Frey and Stutzer, 2002). The question of who are globalization's winners and losers in terms of well-being has so far only been analyzed in one cross-country study (Bjørnskov et al., 2007). The results of this analysis are, however, of limited use since subjective well-being is not internationally comparable (Diener and Oishi, 2006). ${ }^{1}$ To fill this gap, this paper analyzes the effect of globalization on people's life satisfaction drawing on a rich micro dataset for the EU-15 countries from 1975 to 2001.

\section{Theoretical considerations and hypotheses}

The Heckscher-Ohlin theorem provides a clear prediction with regard to globalization's winners and losers. It contends that in a world where production factors are mobile across sectors more liberalized trade induces changes in relative factor prices according to the Stolper-Samuelson theorem. More specifically, in developed regions such as the EU-15 countries the prices of relatively abundant production factors (high-skilled labor) increase, while those of relatively scare production factors (low-skilled labor) decrease. Hence, due to this change in relative wages the well-being of high-skilled workers increases more than that of low-skilled workers (hypothesis 1). ${ }^{2}$ O'Rourke (2006) provides preliminary evidence for this hypothesis by showing that skill-level has a significant influence on voters' support for globalization.

Second, high-income earners are in a better position to benefit from the increased opportunities for traveling and consumption that globalization offers (hypothesis 2). Third, as right-wing voters generally support liberalization, one might suspect that they benefit more from globalization than left-wing voters (hypothesis 3). Fourth, there is reason to believe that globalization's effect on wellbeing varies across age groups since young people may be better prepared and more able to take advantage of the increased opportunities on the international labor market (Doyle and Fidrmuc, 2005) (hypothesis 4). Finally, related to Hudson's (2006) finding of a positive effect of institutional trust on happiness, one could argue that individuals who express confidence in the institutions that promote globalization, i.e. the World Trade Organization (WTO), the World Bank, and the

\footnotetext{
${ }^{1}$ This may also explain why the authors only find a significant effect in one out of eight estimations.

${ }^{2}$ We do not assume a decline in the well-being of low-skilled workers because they do benefit from other aspects of globalization such as opportunities for traveling and increasing product variety.
} 
International Monetary Fund (IMF), are more likely to experience an increase in well-being due to globalization (hypothesis 5$)^{3}$.

\section{Data description and empirical strategy}

Given the evidence for a negative effect of unemployment and inflation on life satisfaction (Di Tella et al. 2001), the estimations include the vector Macro $_{t c}$ representing the growth rate of the consumer price index (OECD Key Economic Indicators) and unemployment rates (OECD Economic Outlook). In addition, the KOF globalization index (based on data from the political, social, and economic sphere) is used as the main independent variable. ${ }^{4}$ Finally, the regressions take into account micro-level variables from the Eurobarometer Survey Series over the 1975 - 2001 period, where Individual $_{\text {itc }}$ includes gender, age, relative income, ideological preferences, marital and employment status, education level and the number of children. The dependent variable - life satisfaction - is based on the question 'On the whole, are you very satisfied (4), fairly satisfied (3), not very satisfied (2) or not at all satisfied (1) with the life you lead?'.

The regression model best suited to the analysis in this paper is an ordered response model, where the dependent variable is discrete and measured on a finite ordinal scale. The first part of the model is a structural equation for the latent, continuous dependent variable:

$$
\text { Lifesat }_{i t c}^{*}=\alpha+\text { BIndividual }_{i t c}+\gamma \text { Globalization }_{t c}+\delta \text { Macro }_{t c}+\omega_{t}+\mu_{c}+\varepsilon_{i t c}
$$

$\varepsilon_{i t c}$ represents an i.i.d. and normally distributed error term. All of the regressions include an intercept $\alpha$, time fixed effects $\omega_{t}$ and country fixed effects $\mu_{c}$. The latter are indispensable since measures of subjective well-being are not internationally comparable.

The second part of the model is an observation rule for the ordinal dependent variable, which relates the observable dependent variable to the latent variable by spelling out how Lifesat $_{\text {itc }} \in\{1,2,3,4\}$ changes its value if Lifesat $_{\text {itc }}{ }^{*}$ crosses a fixed given threshold $\tau_{j}$ :

Lifesat $_{i t c}=\left\{\begin{array}{l}1 \text { if } \text { Lifesat }_{\text {itc }}{ }^{*} \leq \tau_{1} \\ 2 \text { if } \tau_{1}<\text { Lifesat }_{i t c}{ }^{*} \leq \tau_{2} \\ 3 \text { if } \tau_{2}<\text { Lifesat }_{i t c}{ }^{*} \leq \tau_{3} \\ 4 \text { if } \tau_{3}<\text { Lifesat }_{i t c}{ }^{*}\end{array}\right.$

\footnotetext{
${ }^{3} \mathrm{I}$ am indebted to an anonymous referee for the suggestion to extend the analysis by this fifth hypothesis.

${ }^{4}$ For more details on the KOF index see Dreher (2006).

${ }^{5}$ For a description and justification of the control variables see Hessami (2010).
} 
The ordered response model is estimated for fourteen population subgroups:

Low-skilled/High-skilled: Respondents who at most attended school until the age of 15/ at least attended school until the age of 20

Poor/rich: $\quad$ Respondents in the lowest/ highest income quartile

Left-wing/right-wing: Respondents placing themselves on the left/ right of the ideological scale Young/old: $\quad$ Respondents who are at most 30 years old/ older than 50 years

Trust/Do not trust WTO/ Respondents who tend to trust/ not to trust each of these institutions ${ }^{6}$ World Bank/IMF:

\section{Estimation results}

The estimations in table 1 cover the time period from 1975 to 2000 and provide evidence for a significantly positive effect of globalization on well-being across the first eight groups. ${ }^{7}$ Since the coefficients' magnitudes have no meaningful interpretation in microeconometric estimations, the marginal effects at the independent variables' means are reported in squared brackets. The difference is largest across the ideological dimension: with a one-point increase in the globalization index, the probability of being 'very satisfied' with one's life rises by 0.7 percentage points for leftwing voters and 1.5 percentage points for right-wing voters. Given that this index is scaled between 0 and 100 , we can therefore conclude that globalization has a sizable effect on well-being.

The findings for models 7 and 8 provide evidence against hypothesis 4 . They suggest that old people benefit more from globalization than young people. ${ }^{8}$ A potential explanation is that even though a global job market offers more opportunities, it also puts competitive pressure on young people by requiring additional skills such as proficiency in foreign languages from them. In addition, young people may suffer from the difficulties involved in trying to maintain social relationships across borders.

Table 2 reports the estimation results for models 9 to 14 , which serve to investigate hypothesis 5. The regressions are exclusively based on data from one Eurobarometer survey conducted in 2001 since respondents were not asked about their trust in the WTO, the World Bank, and the IMF in any other Eurobarometer survey. Looking at the marginal effects in squared brackets, we can conclude that for individuals who trust these institutions the effect of globalization on well-being is indeed larger. ${ }^{9}$ Summarizing, we cannot reject hypotheses 1 to 3 and 5, while we do reject hypothesis 4 .

\footnotetext{
${ }^{6}$ The exact wording in the questionnaire is "From the following list, who do you trust the most to get the effects of globalisation under control?" with the possibility to select several institutions.

7 Data beyond 2000 has not been included in these estimations given that respondents' number of children and income quartiles are not recorded in the Eurobarometer surveys from 2001 to 2003 and after 2004, respectively.

${ }^{8}$ The difference in marginal effects is even larger when redifining the age groups for instance with a cut-off at 45 years or with the young defined as below 35 years of age and the old defined as 60 years old or over.

9 We have also experimented with respondents' trust in EU institutions but failed to find any significant differences regarding globalization's effect on subjective well-being.
} 
Table 1: Ordered probit estimation results for subgroups (hypotheses 1 to 4), 1975 - 2000

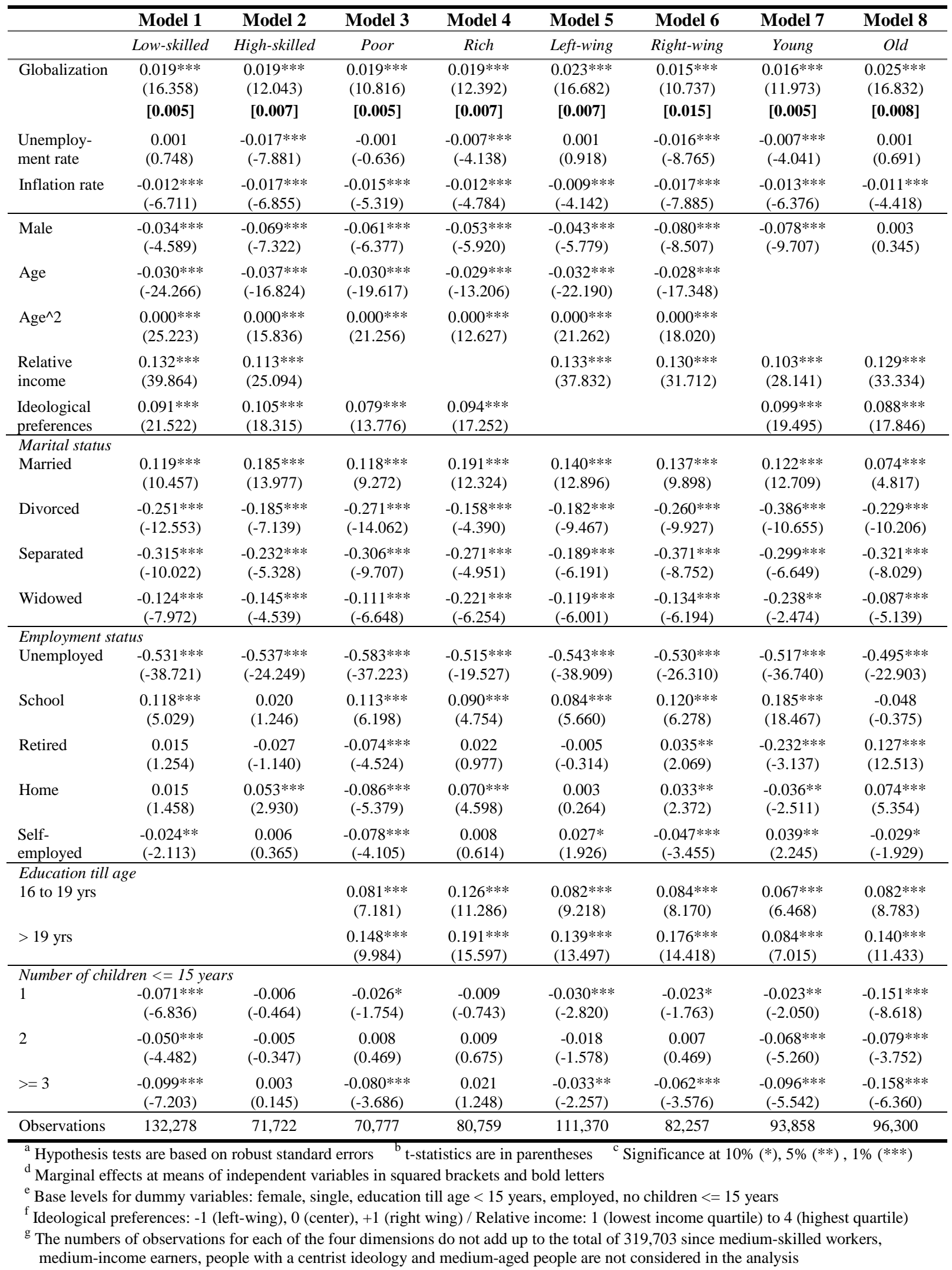


Table 2: Ordered probit estimation results for subgroups (hypothesis 5), 2001

\begin{tabular}{|c|c|c|c|c|c|c|}
\hline & Model 9 & Model 10 & Model 11 & Model 12 & Model 13 & Model 14 \\
\hline & Trust WTO & $\begin{array}{c}\text { Do not trust } \\
W T O\end{array}$ & $\begin{array}{c}\text { Trust World } \\
\text { Bank }\end{array}$ & $\begin{array}{l}\text { Do not trust } \\
\text { World Bank }\end{array}$ & Trust IMF & Do not trust IMF \\
\hline Globalization & $\begin{array}{c}0.054 * * * \\
(4.921) \\
{[\mathbf{0 . 0 1 9}]}\end{array}$ & $\begin{array}{c}0.045 * * * \\
(7.262) \\
{[\mathbf{0 . 0 1 4}]}\end{array}$ & $\begin{array}{c}0.057 * * * \\
(4.546) \\
{[\mathbf{0 . 0 2 1}]}\end{array}$ & $\begin{array}{c}0.038 * * * \\
(6.035) \\
{[\mathbf{0 . 0 1 2}]}\end{array}$ & $\begin{array}{c}0.054 * * * \\
(3.703) \\
{[\mathbf{0 . 0 2 0}]}\end{array}$ & $\begin{array}{c}0.042 * * * \\
(7.441) \\
{[\mathbf{0 . 0 1 3}]}\end{array}$ \\
\hline Unemployment rate & $\begin{array}{c}-0.132 * * * \\
(-3.116)\end{array}$ & $\begin{array}{c}-0.100 * * * \\
(-5.463)\end{array}$ & $\begin{array}{c}-0.036 \\
(-0.772)\end{array}$ & $\begin{array}{c}-0.117 * * * \\
(-6.462)\end{array}$ & $\begin{array}{l}-0.101 * \\
(-1.859)\end{array}$ & $\begin{array}{c}-0.105 * * * \\
(-6.136)\end{array}$ \\
\hline Inflation rate & $\begin{array}{c}-0.080 \\
(-1.426) \\
\end{array}$ & $\begin{array}{c}-0.024 \\
(-0.896) \\
\end{array}$ & $\begin{array}{c}-0.082 \\
(-1.131) \\
\end{array}$ & $\begin{array}{c}-0.030 \\
(-1.183) \\
\end{array}$ & $\begin{array}{c}-0.068 \\
(-0.782) \\
\end{array}$ & $\begin{array}{c}-0.032 \\
(-1.268) \\
\end{array}$ \\
\hline Male & $\begin{array}{l}-0.131 * * \\
(-2.339)\end{array}$ & $\begin{array}{l}-0.071 * * \\
(-2.407)\end{array}$ & $\begin{array}{l}-0.135^{* *} \\
(-2.238)\end{array}$ & $\begin{array}{l}-0.073 * * \\
(-2.530)\end{array}$ & $\begin{array}{l}-0.125^{*} \\
(-1.806)\end{array}$ & $\begin{array}{c}-0.077 * * * \\
(-2.733)\end{array}$ \\
\hline Age & $\begin{array}{l}-0.022 * \\
(-1.860)\end{array}$ & $\begin{array}{c}-0.019 * * * \\
(-3.453)\end{array}$ & $\begin{array}{c}-0.033 * * * \\
(-2.600)\end{array}$ & $\begin{array}{c}-0.018 * * * \\
(-3.367)\end{array}$ & $\begin{array}{c}-0.038 * * \\
(-2.363)\end{array}$ & $\begin{array}{c}-0.018 * * * \\
(-3.497)\end{array}$ \\
\hline $\operatorname{Age}^{\wedge} 2$ & $\begin{array}{l}0.000^{*} \\
(1.766)\end{array}$ & $\begin{array}{c}0.000 * * * \\
(3.577)\end{array}$ & $\begin{array}{c}0.000 * * * \\
(2.866)\end{array}$ & $\begin{array}{c}0.000 * * * \\
(3.353)\end{array}$ & $\begin{array}{c}0.000 * * * \\
(2.590)\end{array}$ & $\begin{array}{c}0.000 * * * \\
(3.507)\end{array}$ \\
\hline Relative income & $\begin{array}{c}0.193 * * * \\
(6.575)\end{array}$ & $\begin{array}{c}0.131 * * * * \\
(8.500)\end{array}$ & $\begin{array}{c}0.166 * * * \\
(5.140)\end{array}$ & $\begin{array}{c}0.138 * * * \\
(9.208)\end{array}$ & $\begin{array}{c}0.193 * * * \\
(5.062)\end{array}$ & $\begin{array}{c}0.134 * * * * \\
(9.167)\end{array}$ \\
\hline Ideological preferences & $\begin{array}{c}0.112 * * * \\
(3.231)\end{array}$ & $\begin{array}{c}0.018 \\
(0.963) \\
\end{array}$ & $\begin{array}{c}0.043 \\
(1.166) \\
\end{array}$ & $\begin{array}{c}0.039 * * \\
(2.096)\end{array}$ & $\begin{array}{c}0.092 * * \\
(2.117)\end{array}$ & $\begin{array}{l}0.030^{*} \\
(1.691)\end{array}$ \\
\hline \multicolumn{7}{|l|}{ Marital status } \\
\hline Married & $\begin{array}{c}0.095 \\
(1.094)\end{array}$ & $\begin{array}{c}0.182 * * * \\
(4.315)\end{array}$ & $\begin{array}{c}0.176^{* *} \\
(2.030)\end{array}$ & $\begin{array}{c}0.167 * * * \\
(3.977)\end{array}$ & $\begin{array}{l}0.201^{*} \\
(1.828)\end{array}$ & $\begin{array}{c}0.164 * * * \\
(4.057)\end{array}$ \\
\hline Divorced & $\begin{array}{c}-0.411 \text { *** } \\
(-3.041)\end{array}$ & $\begin{array}{c}-0.183^{* * * *} \\
(-2.830)\end{array}$ & $\begin{array}{c}-0.340 * * * \\
(-2.788)\end{array}$ & $\begin{array}{c}-0.192 * * * \\
(-2.891)\end{array}$ & $\begin{array}{l}-0.321^{*} \\
(-1.951)\end{array}$ & $\begin{array}{c}-0.210^{* * *} * \\
(-3.362)\end{array}$ \\
\hline Separated & $\begin{array}{c}-0.098 \\
(-0.464)\end{array}$ & $\begin{array}{c}-0.136 \\
(-1.172)\end{array}$ & $\begin{array}{c}-0.019 \\
(-0.084)\end{array}$ & $\begin{array}{c}-0.160 \\
(-1.373)\end{array}$ & $\begin{array}{c}-1.073 * * * \\
(-3.499)\end{array}$ & $\begin{array}{l}-0.044 \\
(-0.407)\end{array}$ \\
\hline Widowed & $\begin{array}{c}-0.069 \\
(-0.472) \\
\end{array}$ & $\begin{array}{c}-0.087 \\
(-1.327) \\
\end{array}$ & $\begin{array}{l}-0.266 * \\
(-1.736) \\
\end{array}$ & $\begin{array}{c}-0.049 \\
(-0.749) \\
\end{array}$ & $\begin{array}{c}0.067 \\
(0.356) \\
\end{array}$ & $\begin{array}{c}-0.096 \\
(-1.519) \\
\end{array}$ \\
\hline \multicolumn{7}{|l|}{ Employment status } \\
\hline Unemployed & $\begin{array}{c}-0.325^{* *} \\
(-2.312)\end{array}$ & $\begin{array}{c}-0.498 * * * \\
(-7.660)\end{array}$ & $\begin{array}{c}-0.472 * * * \\
(-3.283)\end{array}$ & $\begin{array}{c}-0.462 * * * \\
(-7.127)\end{array}$ & $\begin{array}{c}-0.396 * * \\
(-2.263)\end{array}$ & $\begin{array}{c}-0.478 \text { *** } \\
(-7.609)\end{array}$ \\
\hline School & $\begin{array}{c}0.263 * * \\
(2.269)\end{array}$ & $\begin{array}{c}0.218 * * * \\
(3.266)\end{array}$ & $\begin{array}{l}0.242 * \\
(1.911)\end{array}$ & $\begin{array}{c}0.225^{*} * * \\
(3.454)\end{array}$ & $\begin{array}{c}0.201 \\
(1.314)\end{array}$ & $\begin{array}{c}0.236 * * * \\
(3.767)\end{array}$ \\
\hline Retired & $\begin{array}{c}0.134 \\
(1.189)\end{array}$ & $\begin{array}{c}-0.014 \\
(-0.249)\end{array}$ & $\begin{array}{c}0.030 \\
(0.252)\end{array}$ & $\begin{array}{c}0.000 \\
(0.008)\end{array}$ & $\begin{array}{c}-0.154 \\
(-1.047)\end{array}$ & $\begin{array}{c}0.021 \\
(0.399)\end{array}$ \\
\hline Home & $\begin{array}{c}-0.042 \\
(-0.371)\end{array}$ & $\begin{array}{c}-0.055 \\
(-0.980)\end{array}$ & $\begin{array}{c}-0.080 \\
(-0.581)\end{array}$ & $\begin{array}{c}-0.048 \\
(-0.892)\end{array}$ & $\begin{array}{c}0.008 \\
(0.055)\end{array}$ & $\begin{array}{c}-0.056 \\
(-1.062)\end{array}$ \\
\hline Self-employed & $\begin{array}{l}-0.183^{*} \\
(-1.682)\end{array}$ & $\begin{array}{c}0.026 \\
(0.450)\end{array}$ & $\begin{array}{l}-0.165 \\
(-1.562)\end{array}$ & $\begin{array}{l}0.015 \\
(0.264)\end{array}$ & $\begin{array}{r}-0.283 * * \\
(-2.315)\end{array}$ & $\begin{array}{l}0.028 \\
(0.498)\end{array}$ \\
\hline \multicolumn{7}{|l|}{ Education till age } \\
\hline 16 to $19 \mathrm{yrs}$ & $\begin{array}{c}0.072 \\
(0.846)\end{array}$ & $\begin{array}{c}0.096^{* *} * \\
(2.532)\end{array}$ & $\begin{array}{c}-0.063 \\
(-0.691)\end{array}$ & $\begin{array}{c}0.108 * * * \\
(2.870)\end{array}$ & $\begin{array}{c}-0.058 \\
(-0.534)\end{array}$ & $\begin{array}{c}0.104 * * * \\
(2.845)\end{array}$ \\
\hline$>19 \mathrm{yrs}$ & $\begin{array}{c}0.111 \\
(1.268) \\
\end{array}$ & $\begin{array}{c}0.170 * * * \\
(3.999) \\
\end{array}$ & $\begin{array}{c}-0.048 \\
(-0.534) \\
\end{array}$ & $\begin{array}{c}0.191 * * * \\
(4.519) \\
\end{array}$ & $\begin{array}{c}-0.038 \\
(-0.356) \\
\end{array}$ & $\begin{array}{c}0.182^{* * * *} \\
(4.455) \\
\end{array}$ \\
\hline Observations & 2,020 & 6,994 & 1,806 & 7,208 & 1,318 & 7,696 \\
\hline
\end{tabular}

${ }^{\mathrm{a}}$ Notes a to $\mathrm{f}$ for table 1 also apply to table $2 .{ }^{\mathrm{b}}$ Models 9 to 14 use data from Eurobarometer survey 55.1 conducted in April/May 2001. Since there is no information on respondents' number of children in this survey, the corresponding dummies are not included. 


\section{Conclusion}

The empirical analysis in this paper suggests that globalization has benefited especially high-skilled workers, right-wing voters, respondents that trust the WTO, the World Bank, and the IMF as well as relatively wealthy respondents. In addition, globalization has increased well-being to a higher extent for old people than for young people. This may be attributed to the fact that a globalized labor market puts pressure on young people in terms of the skills that they need to master and due to the difficulty of maintaining social relationships across borders. Overall, we find that on the level of the population subgroups that are considered in this study globalization has exclusively created winners in terms of well-being.

\section{References}

Bjørnskov, C., Dreher, A., Fischer, J.A.V., 2007. Cross-country determinants of life satisfaction: exploring different determinants across groups in society. Social Choice and Welfare 30, 11973.

Broda, C., Weinstein, D.E., 2006. Globalization and the Gains from Variety. Quarterly Journal of Economics 121(2), 541-85.

Diener, E., Oishi, S., 2006. Are Scandinavians Happier than Asians? Issues in Comparing Nations on Subjective Well-Being. In: Columbus, F. (Ed.), Politics and Economics of Asia, vol. 10. Nova Science, Hauppauge, NY, 1-25.

Di Tella, R., MacCulloch, R.J., Oswald, A.J., 2001. Preferences over inflation and unemployment: evidence from surveys of happiness. American Economic Review 91, 335-41.

Doyle, O., Fidrmuc, J., 2005. Who Favors Enlargement? Determinants of Support for EU Membership in the Candidate Countries' Referenda. European Journal of Political Economy 22(2), 520-43.

Dreher, A., 2006. Does globalization affect growth? Evidence from a new index of globalization. Applied Economics 38(10), 1091-110.

Dreher, A., Gaston, N., 2008. Has Globalization Increased Inequality? Review of International Economics 16(3), 516-36.

Dutt, A.K., Mukhopadhyay, K., 2005. Globalization and the Inequality among Nations: A VAR Approach. Economics Letters 88(3), 295-99.

Frey, B.S., Stutzer, A., 2002. What Can Economists Learn From Happiness Research? Journal of Economic Literature XL, 402-35.

Hessami, Z., 2010. The Size and Composition of Government Spending in Europe and Its Impact on Well-Being. Kyklos 63(3), 367-403. 
Hudson, J., 2006. Institutional Trust and Subjective Well-Being Across the EU. Kyklos 59(1), 4362.

O'Rourke K., 2006. Heckscher-Ohlin Theory and Individual Attitudes Towards Globalization. In: Findlay, R., Henriksson, R., Lindgren, H., and Lundahl, M. (Eds.), Eli Heckscher, International Trade, and Economic History. MIT Press, Cambridge, 107-38. 